\title{
EDITORIAL
}

\section{Een memorabele vergadering}

\author{
Peter F.A. Mulders
}

Dit nummer van het Nederlands Tijdschrift voor Urologie bevat weer de abstracts, geaccepteerd voor de voorjaarsvergadering in Rotterdam. Deze vergadering is gekoppeld aan het 50-jarig bestaan van de de afdeling Urologie van de Erasmus Universiteit. Een memorabele vergadering wordt dit dus, naast activiteiten en internationale sprekers die deze twee dagen zullen passeren. Naast natuurlijk de inzendingen vanuit Rotterdam, komen de abstracts die geaccepteerd zijn uit het hele land. Overigens waren meer dan 80 abstracts ingezonden! Helaas konden niet alle geaccepteerd worden vanwege de ruimte in het programma. Wellicht dat er nagedacht kan worden om meer artsonderzoekers hun werk te laten presenteren op de NVU-vergaderingen, om meer ruimte te creëren hiervoor. Daarnaast wordt er ook Neder- lands onderzoek gepresenteerd dat al international is gepresenteerd. Onderzoek dat hoog gescoord is doordat het natuurlijk impact heeft. De vraag is of hier ruimte voor moet worden gegeven op andere en extra tijdstippen. Al met al is er een aantal sessies te bedenken die de diversiteit recht aan doet, waarbij oncologie en met name prostaatkanke wederom een prominente plaats zal hebben. Het is goed als de leden van de NVU weer in grote getale komen luisteren naar de voordrachten en hun kritische vragen stellen. Het vergroot de kans om met meer inhoud en reflectie een artikel te schrijven dat een goede kans maakt om in het tijdschrift gepubliceerd te worden.

prof. dr. Peter F.A. Mulders uroloog

$\triangle$ Prof. dr. Peter F.A. Mulders

peter.mulders@radboudumc.nl

Radboudumc, Nijmegen, Nederland

Tijdschrift voor Urologie,

Bohn Stafleu van Loghum, Houten, Nederland 